\title{
YOUTHS' SUSTAINABLE LIVELIHOOD WITH INFORMATION AND COMMUNICATION TECHNOLOGIES: TOWARD AN ICT FOR DEVELOPMENT QUALITY MODEL
}

\author{
Zeinab Zaremohzzabieh, Bahaman Abu Samah, Siti Zobidah Omar, \\ Jusang Bolong and Hayrol Azril Mohamad Shaffril \\ Institute for Social Science Studies (IPSAS), Universiti Putra Malaysia, Malaysia
}

Received 2014-02-27; Revised 2014-03-20; Accepted 2014-04-05

\begin{abstract}
Creating and developing sustainable livelihood opportunities for young people is reliant, in part, on an understanding of the social and economic process and context that affect their lives. The goals of creating youths' sustainable livelihood is to establish appropriate ways to improve the assets on which young people may draw to meet their current and long-term needs and to decrease the challenges they face. Nowadays, the centrality of youth as a target group for ICTs is highlighted. Research findings in the past decade have shown that ICTs are an effective means of broadening livelihood opportunities. Thus, this study examines the conceptual debate about the development of resource strategies, including ICTs, for young people to mobilize their livelihood assets for community development and information-sharing purposes and also to overcome the barriers to using ICTs by suggestinga model and prescriptive guidelines. Going forward, this study provides an account of the cumulative knowledge of how ICTs are used by young people as an integral part of their everyday lives and emphasizesthe importance of selected factors, including affordability, relevance, trust and supportfor the community of practice for the youth community, in utilizing ICTs to expand education, enhance health care, improve assets and develop mechanisms for community support.
\end{abstract}

Keywords: ICT Use, Development, Youths' Sustainable Livelihood, ICT4D Quality Model

\section{INTRODUCTION}

As a part of their community, young people should be accorded suitable sustainable livelihood pathways for them to build productive lives. Creating and developing sustainable livelihood opportunities for young people is reliant, in part, on an understanding of the social and economic process and context that affect their lives and on establishing appropriate ways to improve the assets on which youngpeople may draw to meet their current and long-term needs and to decrease the challenges they face. The idea of sustainable livelihood has increased recently in the field of poverty eradication and community development and many scholars across the globe have focused their main attention on providing livelihood opportunities for

Correspondence Author: Zeinab Zaremohzzabieh, Institute Malaysia Tel: 60-162-831-490 households by targeting adults, but they have failed to take into account the complex nature of young people's sustainable livelihoods. However, youngpeople have an equal opportunity to have asustainable livelihood. For example, some researchers emphasize the importance of youths' sustainable livelihood in how their livelihood activities can contribute significantly to household livelihoods (Robson et al., 2006). They believe that families stronglyvalue the role of the youth in their communities as contributors to household income. The research conducted by Abebe and Kjørholt (2009) has alsostressed that rural young peopleparticipate in household and agricultural production and social reproduction by starting entrepreneurial work in markets. Similarly, another studyhighlights the importance of young people's empowerment in Yemen by using a or Social Science Studies (IPSAS), Universiti Putra Malaysia, 
variety of participatory tools, such as livelihood strategies. The study showed that Yemeni youth and their families are able to identify livelihood skills, that they are interested in self-employment opportunities, and that their contribution to family well-being is the major expense for Yemeni youth (Bakeer et al., 2012). Despite the active role that young people play in their community, they need new resources in order to create more livelihood opportunities to enhance their contribution to family sustenance and the community. Research findings in the past decade have shown that ICTs are an effective means of broadening livelihood opportunities (Lewis, 2004). Nowadays, young peoplestate that owning means of accessing ICTs is a vital factor in their life (Abdullah, 2004). This is not surprising, as they are digitalnativesin the technological era and as would be expected, they areinterested in any technological gadgets and equipment. In addition, ICTs can be used not only as a simple device for communication but also as a way to support themin reducing poverty and inequalityin socioeconomic conditions throughout the world (Sobeih, 2007). Moreover, ICT for Development or ICT4D are potentially helpful in creating new livelihood opportunities for many young people. In order for ICT4D to benefit the youth, the main concern is how ICTs can be used towards creating suitable sustainable livelihood pathways for them to build productive lives (Heeks, 2008; Kleine and Unwin, 2009; Rashid and Elder, 2009; Walsham et al., 2007). While many papers have realized the capacity of ICTs and a useful variety of factors thatenable the link between ICTs and sustainable livelihood in communities, the factors that promote youths' sustainable livelihood are still not sufficiently understood. In this regard, an ICT4D project needs to address these factors to sustain ICT use in a community for its own benefit. In this study these factors are introduced in an ICT4D quality model (Pitula, 2010). The resulting goal model is used to bring sustainable, measurable benefits to communities. This study is also guided by the sustainable livelihoods approach, which is an emerging tool that draws on a pentagon of assets, both tangible and intangible, to improve our understanding of youths' sustainable livelihood at a community level. Thus, a combination of the sustainable livelihoods approach and the ICT4D quality model was created to examine the different phases of ICT for socioeconomic development planned to take sustainable livelihood to youth communities. The application of this study is also to promote the development of resource strategies, including ICTs, for young people to be able to engage in their own capacity-building toward their sustainable livelihood.

\section{SUSTAINABLE LIVELIHOOD}

Sustainable livelihood is a term that is now generally employed in the development discourse and it presents a more coherent and integrated approach to poverty eradication and community development. The concept of sustainable livelihoods was initiated by the Brundtland Commission on Environment and Development and it started circulating in the $1990 \mathrm{~s}$ with the 1992 United Nations Conference on Environment and Development (UNCED). Its ideas are as means of understanding the poverty problem in rural communities. In 1998, the British Department for International Development (DFID) and the Institute for Development Studies (IDS) began taking the sustainable livelihood approach into account. The approach grew from debates on the need to create a powerful tool for participatory community-based research and people-centred learning processes in development. In addition, it encourages the sharing of productive and reproductive roles and giving responsibility forskills and knowledge to groups of individuals (CASL, 1999). It is designed to foster ways of creating a fulfilled and meaningful life for everyone, whatever their position in the community or household, with the chance to contribute deeply to meeting the wants and needs of family, community and society (UNDP, 2001). Without defining poverty, theimportant benefit of the approach is that it shapes the aim as the accomplishment of long-term improvements in livelihoods that involve people's tangible and intangible assets (Scoones, 2009). Access to assets shows that individuals, households, or communities are capable of using them and gives them a reasonable level of competence in building their livelihoods. Our paper reveals that assets can best be understood in terms of the progress that young people make toward establishingtheir livelihood. We considered young people who enhance theirassets over time and thus progress on their way toward achieving sustainable livelihoods. It is helpful to view their situation from their own viewpoint and to experience their existing strategies for building assets to make them individuals who are more likely to achieve a sustainable livelihood. Thus, this study deliberately introduces community development research to the sustainable livelihoods approach, as well as modern methods of researching the opportunities for change within young people in their community. Using this new, positive approach to community-based research allows us to access more information and thus express better solutions. 


\subsection{Youths' Sustainable Livelihoods}

There are common assets that support all young people in the transition from childhood to becoming successful adults. In order to create youths' sustainable livelihoods, it is important to research how to combine young people's assets, both tangible and intangible, in their life.The sustainable livelihood approach usually considers assets in terms of an "asset pentagon" comprised of five facets, including natural, physical, human, financial,and social capital (Soussan et al., 2000; Yassin et al., 2013) and youths' sustainable livelihoods are essentially related to the improvement of these assets. The study conducted in Malaysia shows that human capital is the strongest capital possessed by rural youth $(\mathrm{M}=4.35, \mathrm{SD}=0.53$; Yassin et al., 2013). Education, health status, work skill level, education in entrepreneurship, leadership potential and planning are always associated with a stronger human capital and having this allows young people to escape poverty and leadsthem to accomplish their livelihood strategies (Kabir et al., 2012). For example, AREU (2006) stated that once young people are in the labor market, they start to gain the advantages of previous investment in health and education, continuing to develop the skills needed to increase their livelihood options. The change in youths' contributions to household income has also been connected to changes in howfamilies manage health and education costs for younger family members. Another source of capital that received a high level of mean score $(\mathrm{M}=3.74)$ is social capital (Yassin et al., 2013). Social capital refers to the intangible resources embedded within interpersonal relationships that exist between young peoplein families and communities. In the youth context, this asset refers to help with new ideas, support and encouragement, help with problem-solving and family support (Bakeer et al., 2012). Findings from local studies by (Yassin et al., 2011; Ramli et al., 2013; Shaffril et al., 2011) have demonstrated that there is a solid social relationship between Malaysian youth and their friends, families and communities. This asset can facilitate economic activity and allow young entrepreneurs to be more effective in taking advantage of business opportunities (Abreu et al., 2010; Baregheh et al., 2009; Batjargal, 2003; Burt, 2009; Melia et al., 2010; Rubalcaba et al., 2010; Toivonen and Tuominen, 2009). Natural capital as a third asset is vital to young people whoderivetheir entire livelihood from resource-based activities including forest gathering, fishing, or farming (Yassin et al., 2013). USAID and other donor activities,for instance, have consistently offered their help to young people in fishing communities or remote areas to recover from either natural disasters or armed conflict (USAID, 2007). In addition, physical capital is another asset that helps young people to meet their needs indirectly by providing access to other assets. Affordable transport, secure shelter and buildings, adequate water supply and sanitation, clean, affordable energy and access to information are considered as the physical capital of youths' livelihood activities (Allison and Ellis, 2001; Krantz, 2001; Yassin et al., 2013). Fi nally, financial capitalincludes financial resources (cash, credit/debt, savings and other economic assets, including basic infrastructure and production equipment and technologies) used by young people to achieve a sustainable livelihood and it is the most multipurpose of all the five assets (Moyo, 2009). Financial capital can simply be transformed into other assets by relying on the available processes and transforming structures that are essential for the pursuit of any livelihood strategy (DFID, 2001). Research to date suggests that, for instance, savings accounts for low-income youths may be a high-leverage instrument for attainingfinancial capital. The study indicates that having control over one's savings is related to greater decision-making and the formation of specific savings goals.In particular, studies reveal that vulnerable young people benefit mentally from having savings (Ssewamala et al., 2009). Therefore, financial capital has been recognized as a powerful and effective tool for sustainable livelihoods (Basher, 2010; Kabir Hassan and Tufte, 2001; Schreiner, 2003).

In conclusion, this section demonstrates how young people can achieve sustainable livelihoods through access to a range of livelihood assets. It emphasizes the position of young people as a part of households and the wider community. The basic assumption of many youth programs is that young people need to be supported in order to develop more self-sufficient livelihoods. However, the challenge is to verify how to foster these young people and help them acquire the necessary resources and the relevant competencies to improve their livelihoods and eventually for them to realize the sustainable livelihood pathways that are feasible for themselves and others within their communities.

\section{THE ROLE OF ICTS IN THE LIVES OF YOUNG PEOPLE}

ICTs have become deeply entrenched in young people's daily lives because they are digital natives and are naturally involved with any technological equipment and gadgets (Clark, 2005; Ito et al., 2005). Looking at the global picture, it seems that the large majority of 
young people in the world have access to ICTs of different kinds. For example, statistics from the MAN (2005) in Malaysia show that more than $80 \%$ of Malaysian students talked to friends on Instant Messaging (IM) on a daily basis, $11.5 \%$ of students had their own computer with Internet access and almost $51 \%$ owneda cell phone in 2005. In Australia, about half of young peoplebetween the ages of 14 to 24 have their own mobile phone and the number is rapidly increasing (Gooch, 2002). Similarly, the mobile phone was the most common technology device amongyoung agro-based entrepreneurs in Malaysia, where $98.5 \%$ of respondents owned this device. A survey conducted by the Internet Society of China discovered that a large number of mobile phone users say they surf the Webthrough mobile phone services. In 2004, a survey among rural communities in Mozambique, Tanzania and India in Gujarat province indicated that more than $80 \%$ of the rural community were using broadcast technologies, more than $60 \%$ were using telephony and almost $2 \%$ were using the Internet (Souter, 2005). This provides strong evidence that the huge majority of people in these three areas were not using the Internet. Again, though, the younger generation seem to be greater usersof ICTs when they are present. This is more specifically true for those who need new knowledge, skills and abilities to create opportunities for their sustainable livelihoods. Thus, ICT for Development (ICT4D) presents many new opportunities for young people, as they are so often in the lead in adopting technology innovations and require support.

\subsection{ICT for Development (ICT4D)}

Where ICTs are accessible, communities use them, typically where they can exchange them for more expensive methods of accomplishing particular tasks and they do not require significant new skills or resources, the rebypotentially enhancing the delivery of mainstream development goals (Grunfeld, 2011). I CT for development (ICT4D) has become a global plan for international undertakings around the application of technology to confront numerous social and economic challenges. ICT4D is the use of ICTs to develop the social, cultural, economic and political development of individuals, with the aim of producing social and economic change (Zheng and Stahl, 2011). It includes the use of communication technologies in supporting the necessary information and externalities that can improve the well-being of individuals and communities, mainly in developing countries. In the past decade there has been a vast growth in development programs and plans to design and organize ICT use for development. Many nations have formed national policies to direct the demand for the increase of ICTs toward their nationwide development. The United Nations has a number of its organizations working on ICT and development issues: The UN ICT Task Force and Global Alliance for ICT and Development (GAID) works with stakeholders in many areasregarding the use of ICT to attain numerous globally established development schemas, comprising the Millennium Development Goals (MDGs); UNESCO vigorously emphasizes ICT use for community development, which is part of the program for establishing Multipurpose Community Centers and other projects. Other UN agencies, for examplethe Food and Agriculture Organization (FAO), International Telecommunications Union (ITU), United Nations Development Programme (UNDP) and the World Bank via InfoDev also emphasize ICT4D. Numerous state-owned international development organizations, such as USAID (US), CIDA (Canada), DANIDA (Denmark) and SIDA (Sweden), have plans supporting ICT4D in developing nations. Technology establishments are employed in partnership with governments, donors and NGOs in spreading access to the $70 \%$ of the world population who are unconnected-thus serving a global market plan underneath a more pleasant frame work of ICT4D.

In addition, the rationale for the worldwide attention on ICT use for development and social change is understandable. ICTs are recognized to provide access to information in several regions of human development in the community setting. They have the capacity to foster sustainable livelihoods by assisting in developing thecapital assets of individuals and communities; building the capacity and capability of individuals; improving creative innovations; facilitating social networks; and inspiring social and political participation. If access to ICTs is vital for both economic and social development, the worldwide spread of ICTs is insufficient; more than half of the population, particularly in less developed and developing countries, is yet to be touched by some of these devices and technologies. This makes it supremely important that development programs are involved in spreading access to ICTs. These deliver analytical justifications for organizing development agendas in this direction.How ICTs can help in realizing sustainable livelihoods is summarized in the United Nations Millennium Development Goals (Franklin, 2006; Harris, 2004; Sein and Harindranath, 2004). It is then vital 
that ICT4Demphasizes the creativity of young people in investigating and using ICTs for their own advantage and for the benefit of their families, peers and communities. This is also a new chance for young people to share ideas and learn from peers who have effectively applied ICTs as a key resource in promoting their own economic and social advancement, as well as that of their communities (GAICTD, 2011).

\subsection{ICT4D and Youths' Sustainable Livelihood}

Research into youths' sustainable livelihoods and ICT4D is incomplete and what does occur is more at the conceptual stage, although a limited number of studies have clearly used the sustainable livelihood approach to the study of ICTs in communities. Grimshaw and Gudza (2010) discuss the importance of ICTs for the five livelihood assets by showing in what way access to information can add to improving every asset in the right environment. For instance, human capital can be enhanced via access to information and knowledge about education and training; natural capital via access to institutions that are involved with natural resources; financial capital via access to information on financial associations and facilities; social capital via improved interaction and physical capital via access to market information. In relation to this point, Sridhar and Sridhar (2006) observed that ICTs have the ability to improve non-economic aspects of life such as governance, health and education. Additionally, Duncombe and Heeks (2005) highlight the mobile phone as one of the most important devicesfor improving livelihood assets. In another study on the ability to use ICTs, UNCTAD (2011) identifiedthe position of ICTs in enlarging human and social capital. Furthermore, socioeconomic development researchers have evaluated ICT use in improving education (Rashid and Elder, 2009; Stone, 2004; Traxler and Leach, 2006). Batchelor et al. (2003), on the other hand, interpret the sustainable livelihoods approach in ICT terms to assess the sustainability of ICT projects. It must be considered that ICT use can help young people have access to information and knowledge on a variety of topics that directly influence them, including health, education and employment. This information can be used to improve their sustainable livelihood. Governments can also take advantage of the interest of the young in ICT to alleviate poverty. Moreover, ICTs present new means of addressing the requirements of youth with disabilities, who cannot access traditional sources of information. Vulnerable groups of people can exploit ICTs to make improved links with the community and evolve their educational and employment opportunities (WPAY, 2007). For example, assisting young entrepreneurs in the developing world with education, financing, mentorship and support is an analytical pathway to bridging the digital divide and nurturing the formation of sustainable livelihoods (AHWGYMDGs, 2005). According to Kothari et al. (2004), the operation of the media has broadly been to merge education and entertainment to offer vital messages about health topics, with examples including entertainment programs containing messages about HIV awareness. Generally, access to and use of ICTs can enhance youths' livelihood capabilities by increasing their capacity to make full use of the livelihood potential of the assets available to them.

\subsection{ICT4D Quality Model}

Different models related to ICT4D have so far focused on a variety of factors to facilitate the link between ICT use and sustainable livelihoods. There is no established model for identifying the factors that promote youths' sustainable livelihood. In this study, the importance of these factors is applied to the ICT4D quality model (Pitula, 2010). However, while in a previous study the model were used in elaborating the set of ICT-specific tools, resources and skills that comprise a given project to ensure that they are appropriate for the targeted rural community (Pitula and Radhakrishnan, 2007), the present paper draws on the ICTs quality model to explain why ICTs must be understood within the sociodynamics of a system's sustained use in a community if they are going to contribute to any meaningful development, to sustainable livelihood and to any measurable benefits to the community, particularly its youth. Initially, the models proposed by Pitula (2010) emphasize the interaction of numerous factors in the actual operation and use of ICTs for development in communities. Pitula's model underscores the importance of feasibility, affordability, accessibility, relevance, trust, benefits, sustainability, supportfor a community of practice and cultural appropriateness. She highlights support for a community of practice to bring the model into line with social development through capacitybuilding, while her stress on relevance and cultural appropriateness stimulates ICT as a helpful, permissive tool,from which derives our description of ICT4D projects and the social and cultural features of technology use. In addition, this model is based on Maslow's theory in which a hierarchy of needsinspireshuman behaviour (Huitt, 2004). According to the model, a community's position and setting mainly form its socioeconomic activity, which has the 
opportunity of regulatingthat community's needs. A community is comprised of people who interrelate in many ways. Needs inspire people to organize goals whose accomplishment will result in a measurable gain, which is the inspiring factor for responsibility for that activity. Realizing these goals and needs entailsboth knowledge and action. The three mechanisms of skills, resources and tools may change the person' scondition and thus that of the community, in turn redesigning the environment in which the community is situated. In summary, we recognize a set of factors that an ICT4D project should possess in order to increase its likelihood of achievement. In a previous report, this set of factors for the ICT4D quality model were applied in describing the set of ICT-specific tools, resources and skills that should be included ina given project to guarantee that they are appropriate for the rural society concerned (Pitula and Radhakrishnan, 2007).

\section{ICT FACTORS RELATED TO YOUTHS' SUSTAINABLE LIVELIHOOD}

As part of this study, it is also necessary to identify and analyze the ICT factors related to development that may be seen as constraining a more desirable level of youths' sustainable livelihood. This requires an understanding of what ICT factors shape and influence new livelihood formation and how and the degree to which young people are able to negotiate and shape their own sustainable livelihoods. For this purpose, affordability, relevance, trust and support for a community of practice were selected, which are described below in detail. Following Pitula (2010) suggestion, these factors are able to make ICT tools, resources and skills available for a developmental purpose.

\subsection{Affordability}

However much we are aware of the potential benefit and influence of ICT in youths' sustainable livelihood and development, there is much public concern about a lack of affordable access to relevant information and knowledge services among young people (Wakelin and Shadrach, 2001). The WB (2010) stated that the affordability factor can spread into all sectors to develop living conditions.It canimproveaccess to physical resources, health andyouth training and raise business and household productivity. Affordable access can include purchase costs, continuing operating costs, subscriptions and software licenses, training programs and materials, consultation fees and usage fees to individuals and the community (Pitula, 2010). Knight (1992) also claims that one cost is that of inspiring people to understand collective goals. It is true that young peopletry to find their ownbenefits; they may be reluctant to be involved in a collective effort if they consider that the costs of participating will be greater than the eventual reward. For example, the most negative aspect of mobile phones is cost. Carroll et al. (2002) interviewed a number of young people who faced many problems when they wanted to pay their mobile phone bills. Many school-aged intervieweespaid their bill beforehand because they believed that a prepaid contract is easierto control. The researchers also interviewed a16year-old boy who realized thateven 20 cents perSMS costs a lot of moneyin the end. Of course, this is not a reason for him to stop using SMS, but he is a lot more cautious about the number he sends.

Thus, the emphasis should be on making ICTs widely affordable, which is reasonable given the economic situation of young peopleand the overall community in term of the costs of obtaining, using and then benefiting from ICTs. This view is reinforced by current developments in the ICT area, such as falling ICT costs, resulting from the reducing cost of ICT devices and gadgets and the development of open-source software solutions (SADC, 2004).

\subsection{Relevance}

While there is a great amount of information and services accessible through electronic networks, this may not meet communities' needs for information on agriculture, entrepreneurship, markets, jobs and health, as if the content of the information is inappropriate itwill be useless to thecommunity,particularly if the content is not in its national language (Colle, 2004; 2005; Nor Iadah et al., 2010). According to Pitula (2010), ICT4D is significant and relevant with regard to existing needs and goals, current economic activities and the present knowledge and skill set of individuals and the community. Pade et al. (2009) identified the community'sneed to be involved in local content improvement; that is, there are specific problemsin the rural livelihood setting, so modifying content to meet the needs of users is an important factor in supporting long-term development impact (Best et al., 2009). For example, it is difficult to see any meaningful benefit from ICTs when most of the content on today's Internet is in the English language (Chand et al., 2005; Kuriyan et al., 2010; Moyi, 2003; Parkinson and Lauzon, 2008; Tiwari, 2008). 
However, on the subject of harmful content, attempts to limit youths' access to unpleasant content are increasing (Curtain, 2003); young people need information that is related to educational development, career opportunities and improving their computer and Internet skills and knowledge. This view is supported by the findings of Best and Kumar (2008) that the Chirag kiosks in India fitted with ICT4D failed due to lack of local content. Similarly, Zahurin et al. (2009) indicated that a lack of national content is a matter that needs to be mentioned in the development of digital content in Malaysia. Curtain (2003), in other research, found that almost $32 \%$ of respondents did not use ICTsbecause they were not in accordance with their needsdue to a lack of local content.Thus, in order for the ICT4D project to be significant in the work and daily lives of young people, there must be locally relevant applications. In other words, the local content, such as health information, educational materials, environmental data, or agricultural extension services, has to be helpful to people in the communities.Governments have a further significant role in providing content that is aimed at youth users (Bridges, 2006).

\subsection{Trust}

The ICT4D projects that are available, inspire confidence, reliable and accurate for young users by overcoming the perceptions of risk and uncertainty in usedepend on the overall goal for an ICT4D project, "trust." This may include security, privacy and safety concerns (Li et al., 2009; Pitula, 2010). For example, having a mobile phone imparts feelings of security and safety to a young female, particularly if she is alone at night-time, since she is able to contact others rapidly should an emergency arise (Carroll et al., 2002). Currently, there is a growing amount of work on the relations between trust, ICTs and human development. This has mainly been paying attention to the role of trust in ICT public centers such as kiosks and telecenters (Gomez and Gould, 2010; Rajalekshmi, 2008), in ICTenabled services like mobile banking (Morawczynski and Miscione, 2008), in information (Chepiatis, 2002) and inthe provision of ICT services such as e-government (Kuriyan and Ray, 2009). In terms of underlining the relations between institutional and interpersonal trust, there are several articles explain the varying layers of trust within these ICT initiatives. For example, Rajalekshmi (2008) discusses the role of trust in the relationship between citizens and human intermediaries in the way e-governance services are provided in telecenters. He focuses on the trust in services such as agriculture and how the institutional affiliation of the intermediary is considered to be important for egovernance service delivery to be effective. In other research, Gomez and Gould (2010) observedaround 25,000 people at public access venues include telecenters, public libraries and cyber cafés across several countries to recognize how trust and perceptions shape ICT use. In this study, four dimensions of trust were identified: Safety, perceptions of relevance, perceptions of reputation and the fourth dimension, the "cool factor," which is defined as synonymous with youth (Gomez and Gould, 2010). Levin and Cross (2004) also considered trust as an importantelement for the receipt of tacit knowledge in virtual communities. In addition, lack of privacy in public access can constrain use (Ballantyne, 2004; McKemey et al., 2003; Miller, 2004). Support in this area is seriously inclined toward the Internet (Norris, 2001) and its use among development experts (Rohde, 2004). Commentators call for a degree of "logical doubt" toward statements encouraging the distribution of ICT for creating trust and suggest that, whatever the association between online social relationships and trust, studies of these facts are as yet too much in their infancy to yield any useful assumptions.

\subsection{Supportfor a Community of Practice}

Without experience in ICT practices, members of a community are likely to struggle to picturehow a particular technology might be helpful to them, let alone to learn in what way to use it themselves in order to generate profits and new opportunities.In practice, young people need information on educational development and career opportunities and ways of improving their knowledge (Omar et al., 2013), in particular to achieve a sustainable livelihood. At the individual level, one way of making such connections to the source of knowledge is to involve people in virtual knowledge communities (Wasko and Faraj, 2005). Following today's unparalleled development of electrical communication ability and infrastructure establishment, Computer-Mediated Communication (CMC) makes relational networking more appealing and influential by removing the environmental and temporal barriers that exist in traditional face-to-face interaction (Kang and Yang, 2006). Such groups have become recognized as a community of practice, a set of individuals easily bound together by shared passion, expertise and interests in a joint enterprise (Wenger and Snyder, 2000). With the development of the Internet and the existence of ICTs, interest in spreading communities of practice to online 
environments hasadvanced. Moving a community of practice online poses the potential to decrease the cost of face-to-face meetings and enables interactionamong young people. As more online communities of practice have formed, studies of them have emerged. A community of practice allows absolute research to be undertaken relating to young people's technological practices, the communities into which they fit,and how practices transfer and affect one another during school and in out-of-school communities (Ismail, 2013). This kind of knowledge-sharing is relevant to the open knowledge online of a community of practice that is not controlled by an organizational environment. Blau (1992) postulates that people can become involved in social relationshipson the assumptionthat this will bring social prizes such as admiration, support and position in some way. This is one possible rationale that a person can use for active participation in a community network (Wasko and Faraj, 2005). Accordingly, when introducing a new ICT artefact, it is essential to address the existence of a linked community of practice. There are many elements involved in creating such a community ofpractice. Ramirez (2001) also explained that for a community to become involved, it is necessary to develop the skills and support to make the technology suitable for the community's own purposes. According to Pitula (2010), ICT4D projects can improve and maintain alearning place and spacein which community members can explore a technology's benefits, promote a community of practice through many resources such as communication participation and peer support, encourage both active and passive participation and achieve funding support as a community's abilities and needs develop close working associations among policymakers that let them learn and adjust to one another. These elements cannot be introduced but must be advanced locally, so that ICTs are grounded in the community's understanding and united in its daily activities. The local champions offer the motivation for creating a community vision while the community's grounded organization helps its realization.

\section{CONCLUSION}

The paper explores the concept of youths' sustainable livelihood and provides a suggestion for how ICTs could be an enabler, facilitating the various steps in the process toward achieving the concept. Moreover, from the discussion of the selected model the paper revealed that ICTs can improve the sustainable livelihood of the youth community if the emphasisis on making ICTs widely affordable and very reasonable, relevant, secure and safe and if participation and peer and funding support for the community's abilities and needs maintain and improve ICT use. This study also leads to the conclusion that what we are recommending is not only about the availability of ICTs for all young people. It is also about supporting particular opportunities for young people who are currently competing with more skilled and experienced adults in all spheres of life, but most of all in the areas of livelihoods and careers. Given the large youth population, for the increasing use of ICTs to develop sustainable future careers and livelihoods, policy-makers and government must re-examine their role in supporting young people.

In addition to the results of the study, we offer the following policy messages:

- ICTs are still the largest source of sustainable livelihood. This is true for young people as well. Improving youths' sustainable livelihood therefore demands an increased investment in the ICT sector

- Addressing the constraints faced will significantly contribute to building a positive attitude and make ICTs attractive to young people

- ICTs are an available source of livelihood. Many young people are involved in ICTs for social networking, but rarelyfor generating income. To achieve this, there is a need for a deliberate investment in building ICTs and in regulations such as copyright laws and facilities for ICT use

- ICTs play a critical role in providing a sustainable livelihood for young people. In order for ICTs systematically and effectively to benefit young people, the state needs to have a formal strategy of using ICTs. On the basis of these proposals, ICT programs can be designed to respond precisely to youth poverty and the need for a sustainable livelihood

\section{REFERENCES}

Abdullah, M.Y.H., 2004. Adoption of Cellular Phone Among Young Adults: A study Among Youths in the Klang Valley, Malaysia. In: Mobile Communication and Social Change, SK Telecom., Seoul, pp: 305-312.

Abebe, T. and A.T. Kjørholt, 2009. Social actors and victims of exploitation working children in the cash economy of Ethiopia's South. Childhood, 16: 175194. DOI: $10.1177 / 0907568209104400$ 
Abreu, M., V. Grinevich, M. Kitson and M. Savona, 2010. Policies to enhance the "hidden innovation" in services: Evidence and lessons from the UK. Service Indust. $\quad$ J., $\quad 30$ : 99-118. DOI: $10.1080 / 02642060802236160$

AHWGYMDGs, 2005. Youth and the Millennium Development Goals: Challenges and Opportunities for Implementation. Final Report of the and Ad Hoc Working Group for Youth and the MDGs.

Allison, E.H. and F. Ellis, 2001. The livelihoods approach and management of small-scale fisheries. Marine Policy, 25: 377-388. DOI: 10.1016/S0308597X(01)00023-9

AREU, 2006. Settlement and social networks. Research and Evaluation Unit, Kabul, Afghanistan.

Bakeer, S.B., L. Maas, L. Sabbarini, S. Conklin and L. Dershem, 2012. Measuring impact of young people's empowerment in Yemen-setting a baseline. World Bank.

Ballantyne, D., 2004. Pathways less traveled to value creation: Interaction, dialogue and knowledge generation. J. Bus. Indust. Market., 19: 97-98. DOI: 10.1108/08858620410523972

Baregheh, A., J. Rowley and S. Sambrook, 2009. Towards a multidisciplinary definition of innovation. Manage. Decis., 47: 1323-1339. DOI: 10.1108/00251740910984578

Basher, M.A., 2010. Promotional role of microcredit: Evidence from the Grameen Bank of Bangladesh. J. Int. Dev., 22: 521-529. DOI: 10.1002/jid.1583

Batchelor, S., P. Norrish, N. Scott and M. Webb, 2003. Sustainable ICT case histories. Department for International Development, UK.

Batjargal, B., 2003. Social capital and entrepreneurial performance in Russia: A longitudinal study. Organiz. Stud., 24: 535-556. DOI: 10.1177/0170840603024004002

Best, M.L. and R. Kumar, 2008. Sustainability failures of rural telecenters: Challenges from the Sustainable Access in Rural India (SARI) project. Inform. Technol. Int. Dev., 4: 31-31. DOI: 10.1162/itid.2008.00025

Best, M.L., D. Thakur and B.E. Kolko, 2009. The contribution of user-based subsidies to the impact and sustainability of telecenters-the ecenter project in Kyrgyzstan. Proceedings of the International Conference on Information and Communication Technologies and Development, Apr. 17-19, IEEE Xplore Press, Doha, pp: 192-200. DOI: 10.1109/ICTD.2009.5426709
Blau, P.M., 1992. The American occupational structure. American Sociological Association, NW. Washington D.C.

Bridges, 2006. Real access/Real impact criteria.

Burt, R.S., 2009. Structural Holes: The Social Structure of Competition. 1st Edn., Harvard University Press, Cambridge, ISBN-10: 0674029097, pp: 324.

Carroll, J., S. Howard, J. Peck and J. Murphy, 2002. No 'to a free mobile: When adoption is not enough. Proceedings of the 13th Austrian Conference on International Systems, (ACIS' 02), Association for Information Systems, Australia, pp: 1-11.

CASL, 1999. Participatory research for sustainable livelihoods: A guide for field projects on adaptive strategies: Participatory Rural Appraisal (PRA). Community Adaptation and Sustainable Livelihoods.

Chand, A., D. Leeming, E. Stork, A. Agassi and R. Biliki, 2005. The impact of ICT on rural development in Solomon Islands: The PFNET case. Prepared for ICT Capacity Building at USP Project.

Chepiatis, E., 2002. Soft barriers to ICT application in development: Trust and information quality in Russia. J. Int. Dev., 14: 51-60. DOI: 10.1002/jid.871

Clark, L.S., 2005. The Constant Contact Generation: Exploring Teen Friendship Networks Online. In: Girl Wide Web: Girls, the Internet and the Negotiation for Identity, Mazzarella, S.R. (Ed.), Peter Lang, New York, ISBN-10: 0820471178, pp: 203-222.

Colle, R.D., 2004. ICTs, telecenters and community development. Information Technologies and International Development.

Curtain, R., 2003. Creating more opportunities for young people using information and communications technology. Curtain Consulting.

DFID, 2001. Sustainable livelihoods guidance sheets. Department for International Development, London, UK.

Duncombe, R. and R. Heeks, 2005. Information and Communication Technologies (ICTs), poverty reduction and micro, small and Medium-Scale Enterprises (MSMEs): A framework for understanding ICT applications for MSMEs in developing countries. A Panel at the World Summit on the Information Society, Tunis.

Franklin, M., 2006. Suggested best practice for pursuing development and poverty reduction through national ICT strategies. J. Eastern Caribbean Stud., 31: 85104. 
GAICTD, 2011. Youth and ICT as agents for change. United Nations Department of Economic and Social Affairs, Global Alliance for ICT and Development, New York.

Gomez, R. and E. Gould, 2010. The "cool factor" of public access to ICT: Users' perceptions of trust in libraries, telecentres and cybercafés in developing countries. Inform. Technol. People, 23: 247-264. DOI: $10.1108 / 09593841011069158$

Gooch, L., 2002. Upwardly mobile and soft targets. CheapMobilePhone.

Grimshaw, D.J. and L.D. Gudza, 2010. Local voices enhance knowledge uptake: Sharing local content in local voices. Electr. J. Inform. Syst. Dev. Countr., 40: $1-12$.

Grunfeld, H., 2011. The contribution of information and communication technologies for development (ICT4D) projects to capabilities, empowerment and sustainability: A case study of iREACH in Cambodia. Victoria University.

Harris, R., 2004. ICT for poverty alleviation. UNDPAPDIP, Kuala-Lumpur.

Heeks, R., 2008. ICT4D 2.0: The next phase of applying ICT for international development. Computer, 41: 26-33. DOI: 10.1109/MC.2008.192

Huitt, W., 2004. Taxonomy of the cognitive domain. Educational Psychology Interactive.

Ismail, N., 2013. Using communities of practice to study Malaysian youths' use of New Media. Malaysian J. Commun., 29: 99-112.

Ito, M., D. Okabe and M. Matsuda, 2005. Personal, Portable, Pedestrian: Mobile Phones in Japanese Life. 1st Edn., MIT Press, Cambridge, ISBN-10: 0262090392, pp: 357.

Kabir Hassan, M. and D.R. Tufte, 2001. The x-efficiency of a group-based lending institution: The case of the Grameen Bank. World Dev., 29: 1071-1082. DOI: 10.1016/S0305-750X(01)00014-6

Kabir, M.S., X. Hou, R. Akther, J. Wang and L. Wang, 2012. Impact of small entrepreneurship on sustainable livelihood assets of rural poor women in Bangladesh. Int. J. Econom. Finance, 4: 265-280. DOI: 10.5539/ijef.v4n3p265

Kang, H.S. and H.D. Yang, 2006. The visual characteristics of avatars in computer-mediated communication: Comparison of internet relay chat and instant messenger as of 2003. Int. J. Human Comput. Stud., 64: 1173-1183. DOI: 10.1016/j.ijhcs.2006.07.003
Kleine, D. and T. Unwin, 2009. Technological revolution, evolution and new dependencies: what's new about ict4d? Third World Q., 30 1045-1067. DOI: $10.1080 / 01436590902959339$

Knight, J., 1992. Institutions and Social Conflict. 1st Edn., Cambridge University Press, Cambridge, ISBN-10: 0521421896, pp: 234.

Kothari, B., A. Pandey and A.R. Chudgar, 2004. Reading out of the idiot box: Same-language subtitling on television in India. Inform. Int. Dev., 2: 23-44. DOI: $10.1162 / 1544752043971170$

Krantz, L., 2001. The sustainable livelihood approach to poverty reduction. An Introduction, SIDA.

Kuriyan, R. and I. Ray, 2009. Outsourcing the state? Public-private partnerships and information technologies in India. World Develop., 37: 16631673. DOI: 10.1016/j.worlddev.2009.03.005

Kuriyan, R., K. Kitner and J. Watkins, 2010. ICTs, development and trust: An overview. Inform. Technol. People, 23: 216-221. DOI: 10.1108/09593841011069130

Levin, D.Z. and R. Cross, 2004. The strength of weak ties you can trust: The mediating role of trust in effective knowledge transfer. Manag. Sci., 50: 14771490. DOI: $10.1287 / \mathrm{mnsc} .1030 .0136$

Lewis, C., 2004. Universality and quality of service regulation.

Li, H., M.C. Bliemer and P.H. Bovy, 2009. Modeling departure time choice under stochastic networks involved in network design. J. Transport. Res. Board, 2091: 61-69. DOI: 10.3141/2091-07

MAN, 2005. Young Canadians in a wired world: Phase II student survey. Media Awareness Network.

McKemey, K., N. Scott, D. Souter, T. Afullo and R. Kibombo et al., 2003. Innovative demand models for telecommunications services. CTO and Gamos, UK.

Melia, M.R., A.B. Perez and S.R. Dobon, 2010. The influence of innovation orientation on the internationalization of SMEs in the service sector. Service Industr. J., 30: 777-791. DOI: $10.1080 / 02642060802342679$

Miller, N.L., 2004. Measuring the contribution of infoplazas to Internet penetration and use in Panama. Inform. Technol. Int. Dev., 2: 1-24. DOI: 10.1162/1544752044193443

Morawczynski, O. and G. Miscione, 2008. Examining trust in mobile banking transactions: The case of MPESA in Kenya. Proceedings of the 8th International Conference on Human Choice and Computers, Sept. 25-26, Springer, South Africa, pp: 287-298. DOI: 10.1007/978-0-387-84822-8_19 
Moyi, E.D., 2003. Networks, information and small enterprises: New technologies and the ambiguity of empowerment. Inform. Technol. Dev., 10: 221-232. DOI: 10.1002/itdj.1590100402

Moyo, D., 2009. Dead aid: Why aid is not working and how there is a better way for Africa. Macmillan.

Nor Iadah, Y., A.M.Y. Shafiz, M.A. Zahurin, H.I. Huda and M.K. Khairudin et al., 2010. The influence of community characteristics towards telecentres success. Comput. Inform. Sci., 3: 116-120.

Norris, P., 2001. Digital Divide: Civic Engagement, Information Poverty and the Internet Worldwide. 1st Edn., Cambridge University Press, Cambridge, ISBN-10: 0521002230, pp: 303.

Omar, S.Z., H.A.M. Shaffril, N. Kamaruddin, J. Bolong, and J.L. D'Silva, 2013. Weather forecasting as an early warning system: pattern of weather forecast usage among coastal communities in Malaysia. Life Sci. J.

Pade, C., B. Mallinson and D. Sewry, 2009. An exploration of the critical success factors for the sustainability of rural ICT projects-the dwesa case study. Inform. Syst. Dev. DOI: 10.1007/978-0-38768772-8_26

Parkinson, S. and A.C. Lauzon, 2008. The impact of the internet on local social equity: A study of a telecenter in aguablanca, colombia. Inform. Technol. Int. Dev., 4: 21-38. DOI: 10.1162/itid.2008.00015

Pitula, K. and T. Radhakrishnan, 2007. A set of heuristic measurements for evaluating the inclusiveness of a technology. Proceedings of the International Federation for Information Processing Home Informatics and Telematics, Aug. 22-25, Springer, Chennai, India, pp: 35-48. DOI: 10.1007/978-0-38773697-6_3

Pitula, K., 2010. On requirements elicitation for software projects in ICT for development. PhD Thesis, Concordia University.

Rajalekshmi, K., 2008. E-governance services through telecenters: The role of human intermediary and issues of trust. Inform. Technol. Int. Dev., 4: 19-35. DOI: 10.1162/itid.2007.4.1.19

Ramirez, R., 2001. A model for rural and remote information and communication technologies: A Canadian exploration. Telecommun. Policy, 25: 315-330. DOI: 10.1016/S0308-5961(01)00007-6

Ramli, S.A.B., S.Z. Omar, J. Bolong, J.L. DSilva and H.A.M. Shaffri, 2013. Influence of behavioral factors on mobile phone usage among fishermen: The case of Pangkor Island Fishermen. Asian Social Sci., 9: 162-170. DOI: 10.5539/ass.v9n5p162
Rashid, A.T. and L. Elder, 2009. Mobile phones and development: An analysis of IDRC-supported projects. Elect. J. Inform. Syst. Dev. Countr., 36: 116.

Robson, E., N. Ansell, U. Huber, W. Gould and L.V. Blerk, 2006. Young caregivers in the context of the HIV/AIDS pandemic in sub-Saha ran Africa. Populat. Space Place, 12: 93-111. DOI: 10.1002/psp.392

Rohde, M., 2004. Find what Binds: Building Social Capital in an Iranian NGO Community System. In: Social Capital and Information Technology, Huysman, M. and V. Wulf (Eds.), MIT Press, ISBN10: 0262083310, pp: 75-112.

Rubalcaba, L., J. Gallego and P.D. Hertog, 2010. The case of market and system failures in services innovation. Service Indust. J., 30: 549-566. DOI: 10.1080/02642060903067571

SADC, 2004. Using ICT for reaching the millennium development goals: Moving from rhetoric to action. Swiss Agency for Development and Co-operation.

Schreiner, M., 2003. A cost-effectiveness analysis of the Grameen bank of Bangladesh. Dev. Policy Rev., 21: 357-382. DOI: 10.1111/1467-7679.00215

Scoones, I., 2009. Livelihoods perspectives and rural development. J. Peasant Stud., 36: 171-196. DOI: 10.1080/03066150902820503

Sein, M.K. and G. Harindranath, 2004. Conceptualizing the ICT artifact: Toward understanding the role of ICT in national development. Inform. Society, 20: 15-24. DOI: 10.1080/01972240490269942

Shaffril, H.A.M., B. Abu Samah, J.L. D'Silva and J. Uli, 2011. Global warming at the east coast zone of Peninsular Malaysia. Am. J. Agric. Biol. Sci., 6: 377-383. DOI: 10.3844/ajabssp.2011.377.383

Sobeih, A., 2007. ICT and enterprise development. Sustainable Development Association, Egypt, Alexandria.

Soussan, J., P. Blaikie, O. Springate-Baginski and M. Chadwick, 2000. Understanding livelihood processes and dynamics. Livelihood-Policy Relationships in South Asia Working Paper.

Souter, D., 2005. The Economic Impact of Telecommunications on Rural Livelihoods and Poverty Reduction. Commonwealth Telecommunications Organisation, London.

Sridhar, K.S. and V. Sridhar, 2006. Telecommunications and growth: Causal model, quantitative and qualitative evidence. Econom. Political Weekly, 2611-2619. 
Ssewamala, F.M., C.K. Han and T.B. Neilands, 2009. Asset ownership and health and mental health functioning among AIDS-orphaned adolescents: Findings from a randomized clinical trial in rural Uganda. Soc. Sci. Med., 69: 191-198. DOI: 10.1016/j.socscimed.2009.05.019

Stone, D., 2004. Transfer agents and global networks in the "transnationalization" of policy. J. Eur. Public Policy, 11: 23-23.

Tiwari, M., 2008. ICTs and poverty reduction: User perspective study of rural Madhya Pradesh, India. Eur. J. Dev. Res., 20: 448-461. DOI: $10.1080 / 09578810802245600$

Toivonen, M. and T. Tuominen, 2009. Emergence of innovations in services. Service Industr. J., 29: 887902. DOI: $10.1080 / 02642060902749492$

Traxler, J. and J. Leach, 2006. Innovative and sustainable mobile learning in Africa. Proceedings of the 4th IEEE International Workshop in Wireless, Mobile and Ubiquitous Technology in Education, (UTE '06), IEEE Xplore Press, Athens, pp: 98-102. DOI: 10.1109/WMTE.2006.261354

UNCTAD, 2011. Information economy report 2011, ITCs as an enabler for private sector development. United Nations Publication.

UNDP, 2001. Human Development Report 2000. United Nations Development Program. New York,

USAID, 2007. Adapting to Climate Variability and Change: A Guidance Manual for Development Planning. USAID, Washington DC.

Wakelin, O. and B. Shadrach, 2001. Impact assessment of appropriate and innovative technologies in enterprise development. Manchester: EDIAIS. Manchester.
Walsham, G., D. Robey and S. Sahay, 2007. Foreword: special issue on information systems in developing countries. Manage. Inform. Syst. Q., 31: 317-317.

Wasko, M.M. and S. Faraj, 2005. Why should I share? Examining social capital and knowledge contribution in electronic networks of practice. MIS Q., 35-57.

WB, 2010. World development indicators. World Bank, Washington D.C.

Wenger, E.C. and W.M. Snyder, 2000. Communities of practice: The organizational frontier. Harvard Bus. Rev., 78: 139-146.

WPAY, 2007. World programme of action for youth. United Nations.

Yassin, F., N. Sahari and J. Salim, 2011. A framework of knowledge sharing through ICT for teachers in Malaysia. International Conference on Electrical Engineering and Informatics, pp: 1-5. DOI: 10.1109/ICEEI.2011.6021754

Yassin, S.M., H.A.M. Shaffril and N. Kamaruddin, 2013. Youth's sustainable livelihood strategies: Initial findings from embedded data. Institute for Social Science Studies, Kuala Lumpur.

Zahurin, M.A., H.H. Ibrahim, M.K. Kasiran, N.I. Yusop and Z.M. Dahalin, 2009. Sustaining Telecentres. Management Practice.

Zheng, Y. and B.C. Stahl, 2011. Technology, capabilities and critical perspectives: What can critical theory contribute to Sen's capability approach? Eth. Inform. Technol., 13: 69-80. DOI: 10.1007/s10676011-9264-8 